\title{
Güneş enerjisi santrallerinin yer seçimi için uygunluk haritasının oluşturulmasında klasik ve bulanık mantığa dayalı yöntemlerin analizi: Menemen örneği
}

\author{
Melis Uzar ${ }^{1 *}$ (D) Hüseyin Koca ${ }^{1}$ (D) \\ ${ }^{1}$ Yıldız Teknik Üniversitesi, Davutpaşa Kampüsü, Inşaat Fakültesi, Harita Mühendisliği Bölümü, Esenler, Istanbul, Türkiye.
}

Öz: Geleneksel yöntemler ile enerji üretimindeki sinırlamalar ve çevresel kaygllar neticesinde, yenilenebilir enerjiye doğru hızlı bir yönelim gerçekleşmektedir. Yenilenebilir enerji santrallerinin kurulumu ve işletme esnasındaki verimliliği açısından, yerlerinin seçimi büyük önem taşımaktadır. Bu yüzden tesisler rüzgar, güneş, dalga gibi bulundukları bölgenin özelliklerini kullanarak doğrudan elektrik üretmektedir. Yenilenebilir enerji santrallerinin en yaygınlarından biri ise güneş enerjisi santralleridir (GES). GES'lerin yerlerinin belirlenmesi için literatürde klasik ve bulanık mantığa dayanan birçok yöntem kullanılmıştır. Bu çalışmada, klasik mantığa ve bulanık mantığa dayanan iki farklı yöntemin analizi ile İzmir'in Menemen ilçesi için GES uygunluk haritası oluşturulması amaçlanmıştır. Bu amaçla, klasik mantığa dayanan ilk yöntem analizinde, santralin kuruluşuna etki edecek kriterler Analitik Hiyerarşi Süreci ile ağırlıklandırllmış ve her bir kritere göre uygunluk haritaları oluşturulurken uygunsuz, az, orta ve yüksek olmak üzere 4 kesik değer kullanılmıştır. Bulanık mantığa dayanan ikinci yöntem analizinde ise kriterler Bulanık Analitik Hiyerarşi Süreci ile ă̆ırlıklandırılmış ve her bir kritere göre uygunluk haritaları oluşturulurken uygunluk 0 ile 1 arasındaki değerler ile ifade edilmiştir. Elde edilen analiz sonuçları neticesinde Menemen bölgesine ait güneş enerjisi santralleri kurulumu için, yer seçiminin klasik mantı̆̆a dayanan birinci durumda $\% 65.91$ 'i uygunsuz, \%0.38'i az, \%11.63'ü orta, \%22.08'i ise yüksek uygunlukta olduğu tespit edilmiştir. Bulanık mantığa dayanan ikinci durumda ise yer seçiminin \%65.91'i uygunsuz, \%4.96'sı az, \%13.52 'si orta ve \%15.61'i ise yüksek uygunlukta olduğu tespit edilmiştir.

Anahtar Sözcükler: Güneş enerjisi santrali, Uygunluk analizi, Analitik hiyerarşi süreci, Bulanık analitik hiyerarşi süreci, Çok kriterli karar verme

\section{Analysis of classical and fuzzy-logic based methods to generate suitability maps for solar power plants: The case of Menemen}

\begin{abstract}
As a result of the limitations in energy production and environmental concerns with traditional methods, a rapid trend towards renewable energy has been realized. Site selection is of great importance in terms of renewable power plant installation and their efficiency during operation. Because these facilities produce electricity directly by using the characteristics of their region such as wind, sun and wave. Solar energy is one of the most common renewable energy sources. Many methods based on classical and fuzzy logic have been used in the literature for site selection of solar power plants (SPP). In this study, it is aimed to establish a SPP suitability map for Menemen district of Izmir by two different methods, one based on classical logic and the other based on fuzzy logic. In the first method based on classical logic, the criteria that affect the establishment of the plant were weighted using Analytical Hierarchy Process and four truncated values, inappropriate, low, medium and high, were used when creating suitability maps for each criterion. In the second method based on fuzzy logic, the criteria were weighted by the Fuzzy Analytic Hierarchy Process and suitability was expressed as values from 0 to 1 when establishing suitability map for each criteria. As a final result, it was determined $65.91 \%$ unsuitable, $0.38 \%$ low, $11.63 \%$ medium and $22.08 \%$ high suitability for the region of Menemen solar power plant's installation in the first case based on classical logic. It was determined $65.91 \%$ unsuitable, $4.96 \%$ low, $13.52 \%$ medium and $15.61 \%$ high suitability in the second case based on fuzzy logic.
\end{abstract}

Keywords: Solar power plant, Suitability analysis, Analytical hierarchy process, Fuzzy analytical hierarchy process, Multi criteria decision making 


\section{Giriş}

Nüfus artışı, sanayileşme, refah seviyesinde yükselme ve teknolojik gelişmeler neticesinde enerjiye olan ihtiyaç her geçen gün artmaktadır. $\mathrm{Bu}$ artış çoğunlukla ülkelerin gelişmişlik düzeyleriyle doğru orantılıdır. Türkiye'de de bu artış söz konusudur ve önümüzdeki yıllarda daha fazla olacaktır. Mevcut durumda, enerji ihtiyacı çoğunlukla geleneksel yöntemler ile karşılanmaktadır. Geleneksel yöntemler, fosil yakıtların yakılması sonucu enerji üretimini ifade eder. Bu durum ise birçok siyasi, ekonomik ve çevresel sıkıntıyı beraberinde getirir. Bu bakımdan yenilenebilir enerjiye geçiş zorunluluk arz etmektedir. Türkiye'de yenilenebilir enerjinin en yaygın kullanılanlarından biri güneş enerji santralleridir (GES). GES kurulum maliyetini düşürmek ve işletme esnasında maksimum verimi elde etmek için yer seçimi büyük bir etkendir. GES yerlerinin belirlenmesi birçok teknik, ekonomik ve çevresel kriterlere bağlıdır. Bu kriterler çoğunlukla mekânsal özellik taşıdığından Coğrafi Bilgi Sistemi (CBS) ortamında analizler ile kolaylıkla doğru sonuçlar elde edilebilir. Bu bakımdan da günümüze kadar farklı çok ölçütlü karar verme (ÇÖKV) yöntemleri kullanılarak CBS ortamında birçok çalışma yapılmıştır. ÇÖKV mekanizmalarında sıkça kullanılan analitik hiyerarşi süreci (AHS) yönteminde seçim işlemleri, karar verme aşamasında önceden belirlenen ölçüt puanlamasına göre yapılmakta ve sonuca odak grupları etki etmektedir (Uzar \& Asılhan, 2019). Uyan (2013) Konya’nın Karapınar bölgesi için çevresel ve ekonomik olmak üzere 5 kriter belirlemiş, AHS kullanarak bu kriterleri ağırlıklandırmış ve CBS ortamında yapılan analizler sonucunda GES kurulumu için çalışma alanının \%40.34'ünün uygun, \%59.66’sının uygunsuz olduğunu tespit etmiştir. Potić, Golić ve Joksimović (2016) tarafından Sırbistan’ın doğusunda bulunan Knjazevac bölgesinin güneş enerjisi potansiyelini belirlenmek için yapılan çalışmada iklim, topoğrafya, gün dönümü ve arazi kullanımı olmak üzere 4 kriter belirlenmiştir. Arazi kullanımı, Landsat 8 uydu görüntülerinin analizleri sonucundaki veriler ile 6 sınıf olarak elde edilmiştir. Sonuç haritası ise AHS ve CBS kullanılarak oluşturulmuştur. İran’da GES kurulacak alanların belirlenmesi için Noorollahi, Fadai, Akbarpour Shirazi ve Ghodsipur (2016) tarafından yapılan çalışmada 11 kriter ele alınmıştır. Kriterlerin birbirine göre üstünlükleri kesinlik arz etmediği için ağırlıklandırmada Bulanık Analitik Hiyerarşi Süreci (BAHS) kullanılmış ve CBS ortamında İran için GES uygunluk haritası oluşturulmuştur. Ayrıca, ülkenin 1057 bölgesi göz önünde bulundurularak GES için en uygun bölgeler belirlenmiştir. Al Garni ve Awasthi (2017) tarafindan Suudi Arabistan'ın tamamı için AHS ve CBS kullanılarak yapılan çalışma sonucunda GES için en uygun alanların ülkenin kuzey ve kuzeybatı kesimleri olduğu ortaya çıkmıştır. Bu alanların belirlenmesinde yollara, enerji nakil hatlarına ve yerleşim yerlerine uzaklığın rol oynadığı anlaşılmıştır. Asakereh, Soleymani ve Sheikhdavoodi (2017) tarafından yapılan çalışmada ise BAHS ve CBS kullanılarak İran’ın Khuzestan şehrinde GES kurulacak alanlar belirlenmiştir. Çalışma sonucunda Khuzestan şehrinin çok büyük bir potansiyele sahip olduğu anlaşılmıştır. En kötü senaryoda dahi bu bölgede üretilecek enerjinin, 2013 yılında İran’ın tamamında üretilen enerjinin 1.75 katı olacağı hesaplanmıştır. Aynı zamanda bölgenin güney ve güneybatısına kurulacak istasyonların bu bölgedeki çölleşmeye karşı etkili olacağı düşünülmüştür. Merrouni, Elalaoui, Mezrhab, Mezrhab ve Ghennioui (2018)'deki çalışmada, Fas'ın doğusunda GES kurulacak alanların belirlenmesi için iklim, su kaynakları, konum ve topoğrafya olmak üzere 4 ana kriter ve 8 alt kriter belirlenmiş, AHS ve CBS kullanılarak uygunluk haritası oluşturulmuştur. Çalışmanın sonucunda Fas'ın doğusunun \%19'unu GES kurulumu için yüksek uygunlukta olduğu anlaşılmıştır.

Yapılan literatür araştırmasında, CBS ile uygunluk haritasının oluşturulmasında yaygın olarak AHS ve BAHS yöntemlerinin kullanıldığı tespit edilmiştir. Bu çalışmada ise GES için uygunluk haritasının oluşturulmasında klasik ve bulanık mantığa dayalı yöntemlerin kullanımının karşılaştırılması amaçlanmıştır. Bu amaçla, her iki yöntem kullanıldığında elde edilen analiz sonuçları incelenmiş, yöntemlerin birbirlerine göre avantaj ve dezavantajlarının tartışılması hedeflenmiştir. 


\section{2. Çalışma Alanı ve Kullanılan Veriler}

$\mathrm{Bu}$ çalışmada, İzmir iline bağlı Menemen ilçesi çalışma alanı olarak seçilmiştir (Şekil 1). Menemen, il merkezine 35 km uzaklıkta ve $26^{\circ} 45^{\prime}$ ile $27^{\circ} 05^{\prime}$ doğu boylamları ve $38^{\circ} 25^{\prime}$ ile $38^{\circ} 45^{\prime}$ kuzey enlemleri arasında yer almaktadır. Doğusu Manisa ili, batısı Foça ilçesi ve Ege Denizi, kuzeyi Aliağa ilçesi, güneyi Çiğli ilçesi ile çevrilidir. Yüzölçümü yaklaşık olarak $763 \mathrm{~km}^{2}$ 'dir. Yıllık yağış ortalaması $616 \mathrm{~mm}$, sıcaklık ortalaması ise $19^{\circ} \mathrm{C}$ 'dir. Yıllık ortalama 8 saat güneşlenme süresine sahiptir ve metrekarede yıllık $25000 \mathrm{~kW} / \mathrm{sa}$ güneş enerjisi üretim potansiyeline sahiptir (URL-1). Genel olarak GES kurulumuna uygundur. Bölgede Bakırçay Üniversitesi’ne ait 0.40 mW'lık kurulu güce sahip GES bulunmaktadır (URL-2).

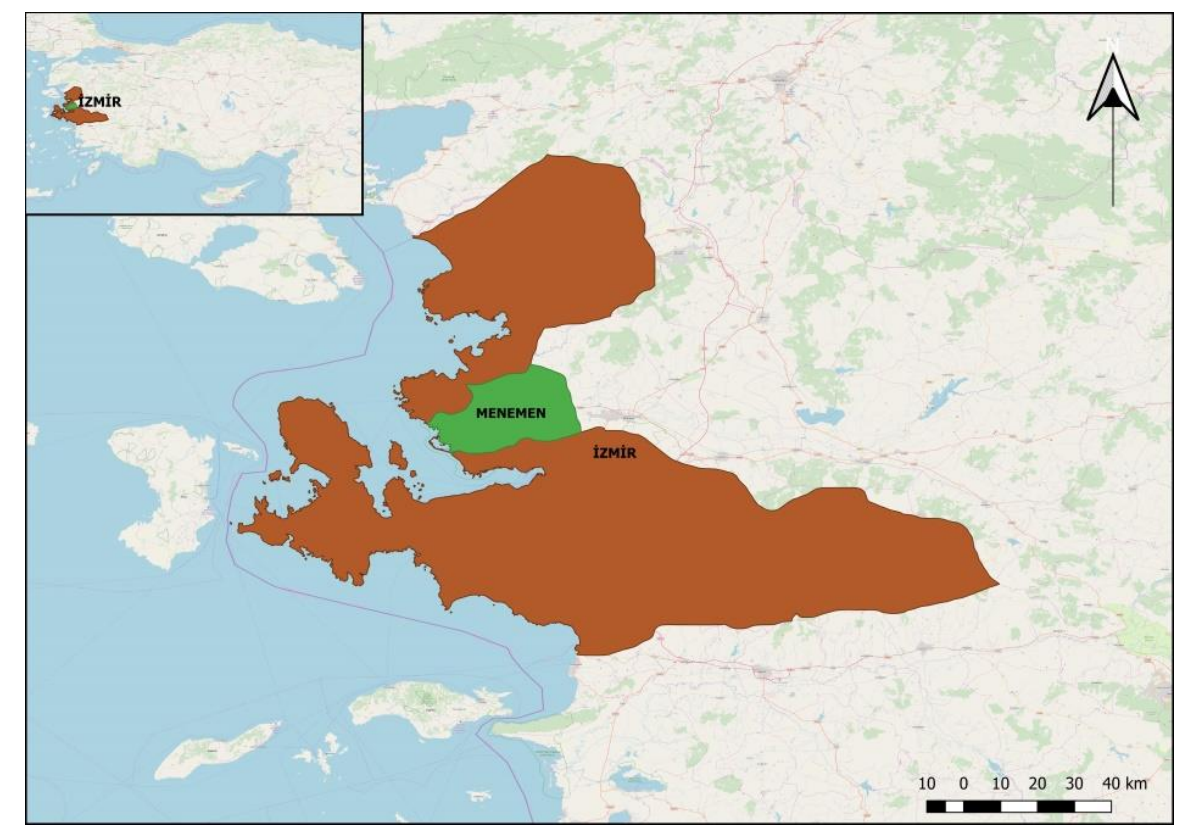

Şekil 1: Çalışma alanı (Open Street Map görüntüsünden derlenmiştir.)

Çalışma alanında kullanılan veriler 1/50 000 ölçekli haritalardan sayısallaştırmak sureti ile elde edilmiştir. Menemen, URLA K-17-c ve İZMİR K-18-d olmak üzere iki adet 1/50 000 ölçekli haritaya denk gelmektedir. Sayısallaştırma işlemi ile 5 adet katman oluşturulmuştur. Yapılan literatür araştırması sonucunda yaygın kullanılan ve çalışma alanı için uygun olan katmanlar seçilmiştir (Asakereh vd., 2017; Uyan, 2013; Noorollahi vd., 2016; Al Garni \& Awasthi, 2017). Bu katmanlar:

- Göller,

- Akarsular,

- $\quad$ Arazi kullanımı,

- Yollar (Karayolları ve demiryolları tek bir katman olarak alınmıştır.),

- Enerji nakil hattından oluşmaktadır.

Bu kriterlerin seçilmesi aşamasında Yenilenebilir Enerji Genel Müdürlüğü’nün bu konuda yapmış olduğu çalışmalar da incelenmiştir. Bu çalışmalarda, genel olarak devlet destekli GES kurulumu için gerekli kriterler yer almakta iken, bunların dışındaki evrensel kriterler bu çalışmamızdaki kriterler ile benzerlik göstermektedir. Ayrıca, Güneş enerji potansiyeli atlası incelendiğinde, ülkenin tamamının güneşlenme değerlerini ifade ettiği gözlenmiştir. Bu atlasta çalışma alanının küçük olması sebebiyle, güneşlenme değerleri çalışma alanının tamamı için benzerlik göstermektedir. Bu sebepten dolayı bu atlas 
kullanılmamıştır. Ülke bazlı veya daha büyük çaplı çalışmalar için ise bu atlastaki değerlerin önemli bir kriter olarak devreye gireceği aşikardır. Bu katmanlara ek olarak ayrıca 30 m x 30 m çözünürlüklü Shuttle Radar Topography Mission (SRTM) verilerinden eğim katmanı elde edilmiştir. Tüm raster veriler, SRTM verileriyle aynı çözünürlükte üretilmiştir.

\section{Metodoloji}

$\mathrm{Bu}$ çalışmada, ilk olarak verilerin elde edilmesi ve kullanıma hazır hale getirilmesi işlemlerini kapsayan ön işleme adımı gerçekleştirilmiştir. Bu adımda 1/50 000 ölçekli topoğrafik haritalar sayısallaştırılmıştır. Ayrıca, bu veriye ek olarak $30 \mathrm{~m} x$ $30 \mathrm{~m}$ çözünürlüklü SRTM verisi de eğim haritası oluşturmak için kullanılmıştır. Verilerin elde edilmesinden sonra GES kurulumuna uygun olmayan kriterler belirlenmiştir. GES kurulumuna etki eden kriterlerin belirlenmesine müteakip iki farklı yaklaşımla uygunluk haritaları oluşturulmuştur. Her iki yaklaşımda da öncelikle GES kurulumuna etki eden kriterler bakımından ayrı ayrı uygunluk haritaları oluşturulmuş sonrasında ise kriterlerin ağırlıkları göz önünde bulundurularak bu haritaların birleştirilmesi ile sonuç haritası elde edilmiştir.

GES için uygunluk haritasının oluşturulmasında ilk yöntem klasik mantığa dayanmaktadır. Bu metotta her bir kritere göre uygunluk haritaları oluşturulurken uygunluklar, uygunsuz, az, orta ve yüksek olmak üzere dört ifade ile belirtilmiştir. Kriterlerin ağırlıklandırılmasında ise AHS kullanılmıştır. Sonuç olarak kriterlerin ağırlıkları esas alınarak uygunluk haritaları birleştirilmiş ve çalışma alanı için GES uygunluk haritası elde edilmiştir. Elde edilen bu haritada uygunluk, uygunsuz (0), az (1), orta (2) ve yüksek (3) olmak üzere dört ifade ile belirtilmiştir.

İkinci yöntem ise bulanık mantığa dayanmaktadır. Bu metotta ise her bir kritere göre uygunluk haritaları oluşturulurken, uygunluklar 0 ile 1 arasındaki bulanık değerler ile ifade edilmiştir. Kriterlerin ağırlıklandırılmasında ise BAHS kullanılmıştır. İlk yaklaşımda olduğu gibi sonuç olarak kriterlerin ağırlıkları esas alınarak uygunluk haritaları birleştirilmiş ve çalışma alanı için GES uygunluk haritası elde edilmiştir. Elde edilen bu haritada uygunluk durumları, 0 ile 1 arasındaki bulanık değerler ile ifade edilmiştir.

Sonuç olarak bu iki yöntemin karşılaştırılmasının yapılabilmesi için bulanık mantıkla elde edilen 0 ile 1 arasındaki uygunluk değerleri; uygunsuz, az, orta ve yüksek olmak üzere dört kesik değere dönüştürülmüş ve iki yöntemin karşılaştırılması yapılmıştır (Şekil 2).

\subsection{Uygun Olmayan Bölgelerin Belirlenmesi}

Bir bölgede GES kurulabilmesi için belirli koşulların sağlanması gerekmektedir. Bu koşullar çalışma amacına ve bölgesine göre değişiklik arz etmektedir. Bu çalışmada uygun olmayan bölgelerin belirlenmesi için, yapılan literatür araştırması (Asakereh vd., 2017; Al Garni \& Awasthi, 2017; Noorollahi vd., 2016; Şenlik, 2017) sonucunda altı adet koşul kullanılmıştır. Bu koşullar;

- Yerleşim yerlerine, yasak bölgelere ve koruma alanlarına 500 m’den yakın olmamak (Arazi kullanımı kategorisinde toplanmıştır.),

- Göllere 400 m'den yakın olmamak,

- Eğimi \%11'in altında olmak,

- Akarsulara 400 m'den yakın olmamak, 
- Demir yollarına 100 m'den yakın olmamak,

- Kara yolarına 100 m'den yakın olmamaktır.

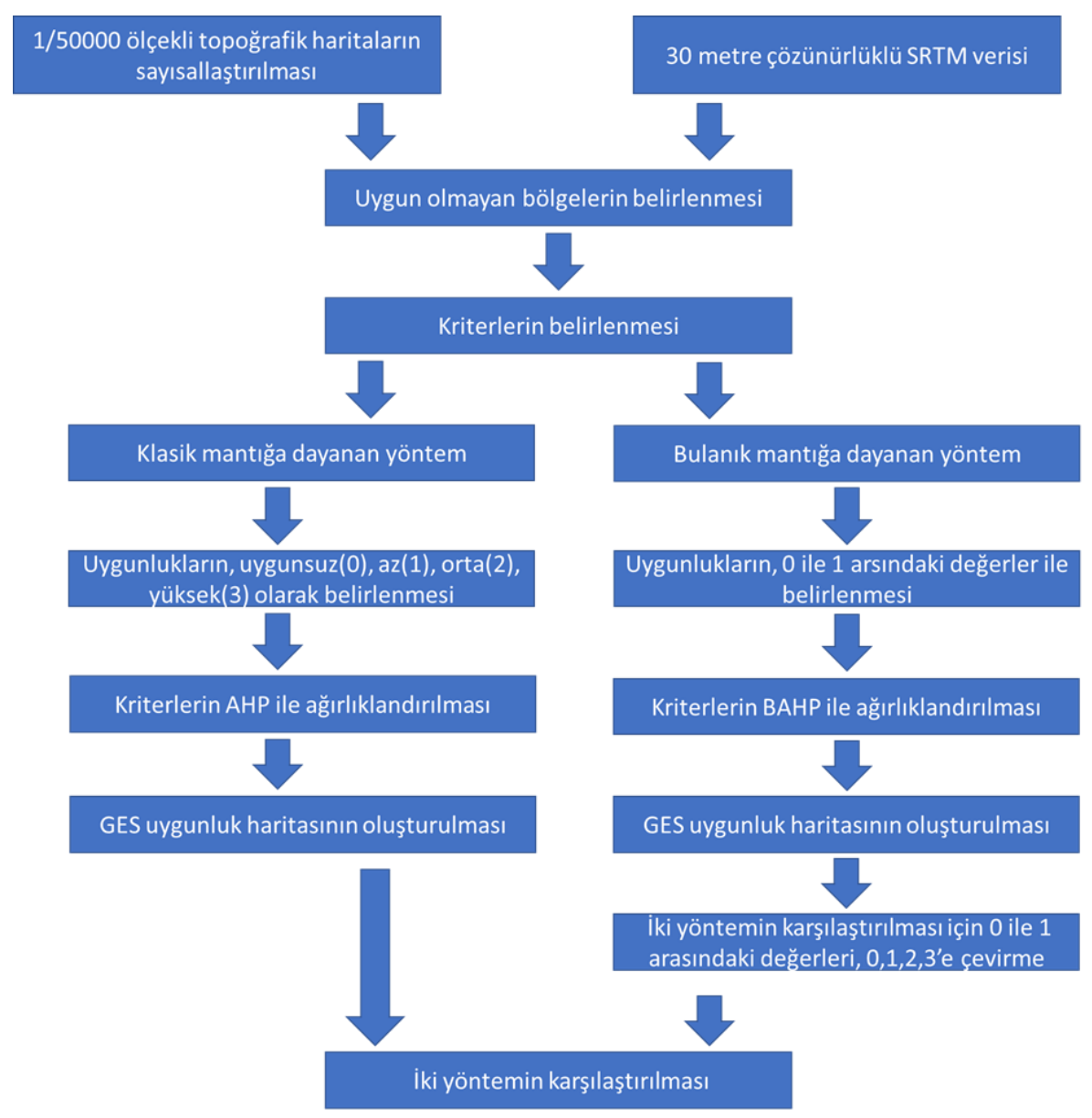

Şekil 2: Iş akış diyagramı

\subsection{Kriterlerin Belirlenmesi}

Kriterler literatür taraması sonucunda bölgenin özellikleri göz önünde bulundurularak belirlenmiştir. Bu kapsamda toplamda altı adet kriter belirlenmiştir. Bunlar eğim, arazi kullanımı, akarsulara uzaklık, göllere uzaklık, yollara uzaklık (kara ve demir yollarını ifade eder) ve enerji nakil hatlarına uzaklıktır.

\subsubsection{Eğim}

GES'lerin yerlerinin belirlenmesinde en önemli faktörlerden birisi eğim kriteridir. Genel olarak \%11 üzerindeki bölgeler uygunsuz olarak kabul edilir. \%4 ve altı eğim ise uygun olarak görülmektedir. Fazla eğim güneş panellerinin birbirine gölge yapmasına neden olacağından verimlilik etkilenebilmektedir. Bunun yanında yüksek eğim, santralin kurulum maliyetini arttırmaktadır (Noorollahi, 2016).

\subsubsection{Arazi Kullanımı}

Arazi kullanımı yerleşim yerlerini, yasak bölgeleri ve koruma alanlarını ifade eder. GES'lerin bu bölgelere belirli mesafede olmaları gerekmektedir. Çünkü yerleşim yerleri her geçen gün büyümektedir. Uzun vadede düşünüldüğünde ise GES’lerin bu bölgeler içinde kalma ihtimalleri vardır. Ayrıca, GES kurulması oradaki doğal yaşamı etkileyeceği için koruma alanlarından da belirli bir mesafe uzaklıkta olması gereklidir. Ayrıca, arazi kullanımı açısından GES için yer seçimi yapılacak alandaki doğal bitki örtüsü gölgelemeyi arttırmakta ve bu da verimliliği düşürmektedir. Bu bakımdan ağaç örtüsünün 
bulunduğu alanlar ile doğal bitki örtüsünün engel oluşturabileceği makilik, çalılık, sazlık gibi alanlar yer seçiminde öncelikli olarak tercih edilmemekte, ayrıca bu alanların temizlenmesi ek maliyetlere neden olmaktadır (Şenlik, 2017). Bu nedenle genel olarak GES'lerin bu bölgelere 500 m’den yakın olmaması gerektiği kabul edilir.

\subsubsection{Akarsulara Uzaklık}

Mevsimsel olarak yaşanan değişimler (taşkınlar ve yılın belirli zamanlarında debilerin artması) ve uzun süreli akarsu yatağında yaşanan yer değişimleri akarsulara olan uzaklığı etkileyen önemli faktörlerdendir. Bu sebeplerden dolayı GES'lerin taşkınlardan etkilenmemesi ve santrale kolay ulaşımın sağlanması için GES’ler akarsulardan en az 400 m uzaklıkta olmalıdır.

\subsubsection{Göllere Uzaklık}

Yılın farklı zamanlarında, göllerin hacimlerinin değişiklik göstermesi sebebi ile göllerde yaşanacak taşkınların oluşturacağ olumsuz etkilere karşı alınacak güvenlik gerekçesi ve çevresel kirliliğin önlenmesi amaçlı GES'lerin göllerden en az $400 \mathrm{~m}$ uzaklıkta olması istenir.

\subsubsection{Yollara Uzaklık}

Kara ve demir yollarından geçen araçların çevreye bıraktığı atıklar güneş panellerini olumsuz etkilemektedir. Aynı zamanda GES'lerin bu bölgelere yakın olması güvenlik açısından da önemli sıkıntılar doğurmaktadır. Genel olarak literatürde, GES'lerin yollara 100 m'den yakın olmaması kabul görmüştür.

\subsubsection{Enerji Nakil Hattına Uzaklık}

Enerji Nakil Hatlarının (ENH) kurulum maliyeti düşünüldüğünde GES kurulumunda en önemli kriterlerden birinin ENH'lerden olan uzaklık olduğu anlaşılır. Genel olarak kurulacak GES'in enerji nakil hattına $6000 \mathrm{~m}$ 'den (6 km) uzak olmaması istenir (Uyan, 2013; Eroğlu, 2018; Gül, Karakoç \& Rehimbeyli, 2017).

\subsection{Klasik Mantığa Dayanan Yöntem}

İlk aşamada, belirtilen her bir kriter bakımından uygunluk haritaları oluşturulmuştur. Her bir kriter için ayrı ayrı uygunluk haritaları oluşturulurken Tablo 1'de gösterilen değerler kullanılmıştır. Tablo 1'deki değerler literatür taraması sonucunda belirlenmiştir (Asakereh vd., 2017; Al Garni \& Awasthi, 2017; Noorollahi, 2016; Şenlik, 2017). Bu tabloda her bir pikselin, uygunluk bakımından dört $(0,1,2,3)$ kesik değer aldığı görülmektedir. İkinci aşamada ise kriterler AHS kullanılarak ağırlıklandırılmıştır.

Tablo 1: Kriterler için uygunluk seviyeleri

\begin{tabular}{cllll}
\hline KriterlUygunluk & Uygunsuz (0) & Az (1) & Orta (2) & Yüksek (3) \\
\hline Eğim (\%) & $>11$ & $11-8$ & $8-4$ & $<$ \\
\hline Arazi Kullanımı (m) & $<500$ & $500-1000$ & $1000-1500$ & $>1500$ \\
\hline Akarsulara Uzaklık (m) & $<400$ & $400-800$ & $800-1200$ & $>1200$ \\
\hline Göllere Uzaklık (m) & $<400$ & $400-800$ & $800-1200$ & $>1200$ \\
\hline Yollara Uzaklık (m) & $<100$ & $100-200$ & $200-300$ & $>300$ \\
\hline Enerji Nakil Hatlarına Uzaklık (m) & $>6000$ & $6000-4000$ & $4000-2000$ & $<2000$ \\
\hline
\end{tabular}

\subsubsection{Analitik Hiyerarşi Süreci}

Günümüzde doğru karar verme sürecinde karar vericilere en ideal sonuçların sunulması oldukça önemlidir. Bu durum özellikle GES için uygun harita oluşturulması konusunda farklı kriterlerin ele alındığı kapsamda dikkatle ele alınmalıdır. İki alternatif arasında tek bir kritere göre karar vermek oldukça basit bir işlemdir. Bu iki alternatifi karşılaştırırken kriterler ne kadar artarsa, karar süreci de o kadar karmaşık hale gelmektedir. Ayrıca, bu karar aşamasına ikiden çok alternatif eklenirse, problem oldukça karmaşık hale dönüşmektedir. AHS bu durumda devreye girer ve karar vericiye kolaylık sağlar. AHS, 
Thomas Saaty (Saaty \& Vargas, 2012) tarafından geliştirilmiş olup, farklı problemlerin çözümünde birçok araştırmacı tarafından kullanılmıştır (Asakereh vd., 2017; Al Garni \& Awasthi, 2017; Potić vd., 2016; Denizhan, Yalçıner \& Berber, 2017; Uzar \& Şener, 2019). AHS birden çok kriter ve alternatifin söz konusu olduğu durumda, tüm kriterleri bir arada değerlendirmek yerine, her bir kriteri kendi aralarında çiftler halinde değerlendirmeye dayanmaktadır. Başka bir ifadeyle, kriterler ikili karşılaştırmalar yapılarak kolaylıkla ağırlıklandırılır.

AHS yöntemi birden çok aşamadan oluşmaktadır. İlk aşamada, Şekil 2’de gösterildiği gibi bir hiyerarşi modeli kurulmalıdır. $\mathrm{Bu}$ model, alternatifler, kriterler ve hedeften oluşur. Kriterler alt kriterlere de ayrılabilir. İkinci aşamada, her bir kriterin çift olarak karşılaştırması yapılıp, ikili karşılaştırma matrisi oluşturulur (Tablo 2). İkili karşılaştırma matrisinde kullanılan sayılar, kriterlerin üstünlüklerine göre verilir. AHS yöntemini geliştiren Thomas Saaty tarafından belirlenen bu sayılar Tablo 3’te gösterilmiştir (Saaty \& Vargas, 2012). Ağırlıkları hesaplamak için ikili karşılaştırma matrisindeki her bir sütun değerleri toplanır, her bir hücre kendi sütun toplamına bölünür ve o hücrenin yeni değeri hesaplanır. Üçüncü aşamada ise satırlar toplanır ve bu değer kriter sayısına bölünerek her bir kriterin ağırlığı hesaplanır.

Tablo 2: AHS için ikili karşılaştırma matrisi

\begin{tabular}{ccccc}
\hline & Kriter A & Kriter B & Kriter C & Ağırlık (w) \\
\hline Kriter A & $\mathrm{a}_{11}$ & $\mathrm{a}_{12}$ & $\mathrm{a}_{13}$ & $\mathrm{w}_{\mathrm{a}}$ \\
\hline Kriter B & $\mathrm{a}_{21}$ & $\mathrm{a}_{22}$ & $\mathrm{a}_{23}$ & $\mathrm{w}_{\mathrm{b}}$ \\
\hline Kriter C & $\mathrm{a}_{31}$ & $\mathrm{a}_{32}$ & $\mathrm{a}_{33}$ & $\mathrm{w}_{\mathrm{c}}$ \\
\hline
\end{tabular}

Tablo 3: AHS için kriterlerin önem derecesi

\begin{tabular}{cl}
\hline Önem & Tanım \\
\hline 1 & Eşit Derece Önemli \\
\hline 3 & Biraz Daha Fazla Önemli \\
\hline 5 & Oldukça Önemli \\
\hline 7 & Çok Daha Önemli \\
\hline 9 & Kesinlikle Daha Önemli \\
\hline
\end{tabular}

Aynı zamanda ikili karşılaştırma matrisi oluşturulduğunda karar vericinin yargılarında tutarlı olup olmadığını belirlemek için tutarlılık oranının (Consistency Ratio, CR) hesaplanması gerekir. CR değerinin üst limitinin 0.10 olması istenir. CR değerini hesaplamak için öncelikle ikili karşılaştırma matrisinin $(\mathbf{A})$ en büyük özvektörünün $\left(\alpha_{\max }\right)$ hesaplanması gerekmektedir (Eşitlik 2).

$D=\left[a_{i j}\right]_{n x n} x\left[w_{i}\right]_{n x 1}=\left[d_{i}\right]_{n x 1}$

$\alpha_{\max }=\frac{\sum_{i=1}^{n} \frac{d_{i}}{w_{i}}}{n}$

CR değerinin hesaplanması için rassallık indeksinin (Random Index, RI) de bilinmesi gerekir. RI değeri kriter sayısına göre farklılık göstermektedir (Tablo 4).

Tablo 4: Rassallık indeksi değerleri (Supçiller \& Çapraz, 2011)

\begin{tabular}{ccccccccccc}
\hline $\mathrm{n}$ & 1 & 2 & 3 & 4 & 5 & 6 & 7 & 8 & 9 & 10 \\
\hline $\mathrm{RI}$ & 0 & 0 & 0.58 & 0.90 & 1.12 & 1.24 & 1.32 & 1.41 & 1.45 & 1.49 \\
\hline
\end{tabular}

Verilen tüm değerler neticesinde Eşitlik 3 ile CR değeri hesaplanır ve bu değerin 0.10'dan küçük bulunması durumunda karşılaştırma matrisinin tutarlı olduğuna karar verilir. 
$C R=\frac{\alpha-n}{(n-1) \cdot R I}$

Sonuç olarak AHS yöntemi ile elde edilen ağırlıklar göz önüne alınarak, her bir kriter için ayrı ayrı oluşturulmuş uygunluk haritaları kullanılarak, çalışma alanı için GES uygunluk haritası elde edilmiştir.

\subsection{Bulanık Mantığa Dayanan Yöntem}

$\mathrm{Bu}$ yöntemde uygunluk haritaları oluşturulması aşamasında, klasik mantığa dayanan ilk yöntemde olduğundan farklı olarak 4 farklı değer yerine 0 ile 1 arasındaki bulanık değerler kullanılmıştır. Böylece, arazi kullanımı açısından uygunluk haritası oluşturulurken, 500 m'den yakın alanlara uygunsuz oldukları için 0 değeri verilmiştir. Çalışma alanında bu kategoriye giren alanlara en uzak nokta 6945 m'de olduğu için bu nokta en uygun nokta olarak 1 değerini almış, diğer noktalar da uzaklıklarına göre 0 ile 1 arasındaki değerleri almışlardır. Eşitlik 4 yardımıyla bu hesaplama yapılmıştır.

$\mu_{\text {Arazi Kullanımı (m) }}=\left\{\begin{array}{cc}0 & x \leq 500 \\ \frac{x}{6945} & x>500\end{array}\right.$

Akarsular bakımından uygunluk haritası oluşturulurken, $400 \mathrm{~m}$ 'den yakın alanlar uygunsuz oldukları için 0 değeri verilmiştir. Çalışma alanında akarsulara en uzak nokta 11496 m’de olduğu için bu alan 1 değerini almıştır. Diğer alanların uygunlukları ise Eşitlik 5 yardımıyla hesaplanmıştır.

$\mu_{\text {Akarsular }(m)}=\left\{\begin{array}{cc}0 & x \leq 400 \\ \frac{x}{11496} & x>400\end{array}\right.$

Göller bakımından uygunluk haritası oluşturulurken, 400 m'den yakın alanlar uygunsuz oldukları için 0 değeri verilmiştir. Çalışma alanında göllere en uzak nokta 11307 m'de olduğu için bu alan 1 değerini almıştır. Diğer alanların uygunlukları ise Eşitlik 6 yardımıyla hesaplanmıştır.

$\mu_{\text {Göller }(m)}=\left\{\begin{array}{cc}0 & x \leq 400 \\ \frac{x}{11307} & x>400\end{array}\right.$

Yollar bakımından uygunluk haritası oluşturulurken, 100 m'den yakın alanlar uygunsuz oldukları için 0 değeri verilmiştir. Çalışma alanında yollara en uzak nokta 5622 m’de olduğu için bu alan 1 değerini almıştır. Diğer alanların uygunlukları ise Eşitlik 7 yardımıyla hesaplanmıştır.

$\mu_{\text {Yollar }(m)}=\left\{\begin{array}{cc}0 & x \leq 100 \\ \frac{x}{5622} & x>100\end{array}\right.$

ENH bakımından uygunluk haritası oluşturulurken, 6000 m'den uzak alanlar uygunsuz oldukları için 0 değeri verilmiştir. Diğer alanların uygunlukları ise Eşitlik 8 yardımıyla hesaplanmıştır. Böylelikle enerji nakil hattına en yakın alan 1 değerini alacak, 6000 m’ye en yakın alan ise 0’a yakın oldukça küçük bir değer alacaktır.

$\mu_{E N H(m)}=\left\{\begin{array}{cc}0 & x \geq 6000 \\ 1-\left(\frac{x}{6000}\right) & x<6000\end{array}\right.$

Eğim bakımından uygunluk haritası oluşturulurken, \%11'in üzerinde eğime sahip alanlar uygunsuz oldukları için 0 değeri verilmiştir. Diğer alanların uygunlukları ise Eşitlik 9 yardımıyla hesaplanmıştır. Böylelikle eğimi 0 olan alanlar 1 değerini alacak, eğim değeri \%11'e yaklaştıkça değer de 0'a yaklaşacaktır. 
$\mu_{E \breve{g} i m}=\left\{\begin{array}{cc}0 & x \geq 11 \\ 1-\left(\frac{x}{11}\right) & x<11\end{array}\right.$

\subsubsection{Bulanık Analitik Hiyerarşi Süreci}

Kriterlerin birbirlerine göre üstünlüklerinin kesinlik içermemesi durumunda AHS yerine BAHS yöntemi tercih edilmektedir. Bu durumda kriterlerin karşıllaştırılmasında Tablo 3'teki gibi tek bir kesin değer ile ifade etmek yerine bulanık değerleri kullanmak çalışmanın tutarlılı̆̆ını arttıracaktır.

$\mathrm{Bu}$ çalışmada, kriterlerin birbirine göre üstünlükleri karar vericilerin görüşlerine göre değişiklik arz etmektedir. Bu nedenle, AHS ile BAHS yöntemleri kullanılarak çıkan sonuçlar karşılaştırılmıştır. Bulanık mantığın AHS'de kullanılmasında birçok değişik yöntem tercih edilmektedir. Bu yöntemlerden yaygın olarak kullanılanlardan biri de Buckley (1985) tarafindan geliştirilen yöntemdir. Buckley (1985)’e göre:

1.Adım: Kriterlerin ikili karşılaştırma matrisi oluşturulur. Burada, AHS'den farklı olarak kriterlerin karşılaştırmasında üçgensel bulanık sayılar (ÜBS) diğer bir ifade ile “triangular fuzzy number” kullanılır (Tablo 5).

Tablo 5: BAHS için kriterlerin önem derecesi

\begin{tabular}{cl}
\hline ÜBS & Tanım \\
\hline $1,1,1$ & Eşit Derece Önemli \\
\hline $1,3,5$ & Biraz Daha Fazla Önemli \\
\hline $3,5,7$ & Oldukça Önemli \\
\hline $5,7,9$ & Çok Daha Önemli \\
\hline $7,9,11$ & Kesinlikle Daha Önemli \\
\hline
\end{tabular}

Birden çok, "k" kadar karar vericinin söz konusu olduğu durumda, her bir karar vericinin görüşlerine göre ayrı ayrı ikili karşılaştırma matrisi oluşturulur. Söz konusu “k.” karar vericinin ikili karşılaştırma matrisi Eşitlik 10’de görülmektedir.

$\tilde{A}^{k}=\left[\begin{array}{ccc}\tilde{d}_{11}^{k} & \cdots & \tilde{d}_{1 n}^{k} \\ \vdots & \ddots & \vdots \\ \tilde{d}_{n 1}^{k} & \cdots & \tilde{d}_{n n}^{k}\end{array}\right]$

2.Adım: Her bir karar vericinin $\tilde{d}_{i j}^{k}$ (k: karar vericinin ÜBS değeri) değeri kullanılarak Eşitlik 11 ile ortalama $\tilde{d}_{i j}^{k}$ (ÜBS’lerin ortalaması) değeri hesaplanır.

$\tilde{d}_{i j}=\frac{\sum_{k=1}^{K} \tilde{d}_{i j}^{k}}{K}$

3.Adım: Ortalama değerlerden oluşan ikili karşılaştırma matrisi Eşitlik 12'de gösterilmiştir.

$\tilde{A}=\left[\begin{array}{ccc}\widetilde{d_{11}} & \cdots & \widetilde{d_{1 n}} \\ \vdots & \ddots & \vdots \\ \widetilde{d_{n 1}} & \cdots & \widetilde{d_{n n}}\end{array}\right]$

4.Adım: Her bir kriterin bulanık değerlerinin geometrik ortalaması Eşitlik 13 ile hesaplanır. Buradaki $\tilde{r}_{i}$ (bulanık değerlerinin geometrik ortalaması) halen üçgensel bulanık sayıdır.

$\tilde{r}_{i}=\left(\prod_{j=1}^{n} \tilde{d}_{i j}\right)^{1 / n}, i=1,2, \ldots \ldots \ldots, n$ 
5.Adım: Her bir kriterin bulanık ağırlığı aşağıdaki üç alt adım izlenerek bulunur.

5.1.Adım: Her bir $\tilde{r}_{i}$ değerinin vektör değeri toplamı bulunur. Böylece, her bir sütundaki değerler kendi içerisinde toplanır.

5.2.Adım: Vektör toplamlarının tersi alınır ve artan şekilde sıralanır.

5.3.Adım: Her bir $\tilde{r}_{i}$ değeri, tersi alınan vektör değer ile çarpılır ve kriterlerin bulanık ağırlıkları bulunur.

$\widetilde{w}_{i}=\tilde{r}_{i} \otimes\left(\tilde{r}_{1} \oplus \tilde{r}_{2} \oplus \ldots . . \tilde{r}_{n}\right)^{-1}$

$\widetilde{w}_{i}=\left(l w_{i}, m w_{i}, u w_{i}\right)$

6.Adım: Buradaki $\widetilde{w}_{i}$ (kriterlerin bulanık ağırlıkları) değeri ÜBS'dir. Chou ve Chang (2008) tarafından geliştirilen alanın merkezi yöntemi ile normal sayı haline getirilmelidir.

$M_{i}=\frac{l w_{i}+m w_{i}+u w_{i}}{3}$

7.Adım: $M_{i}$ (kriterlerin ağırlıkları) bulanık sayı değildir, fakat Eşitlik 16 ile normalize edilmesi gerekir.

$N_{i}=\frac{M_{i}}{\sum_{i}^{n} M_{i}} \quad\left(\mathrm{~N}_{\mathrm{i}}\right.$ : kriterlerin normalize ağırlıkları)

Yedinci adımla birlikte tüm kriterlerin normalize edilmiş ağırlıkları hesaplanmıştır. Daha sonra her bir kriterin ağırlığı, ilgili alternatif ile çarpılarak alternatifin puanı hesaplanır. Bu sonuçlara göre en yüksek puana sahip alternatif, karar verici için istenen seçenektir (Ayhan, 2013).

\section{GES İçin Uygunluk Haritalarının Oluşturulması}

Bu çalışmada ilk adımda her iki yöntemde de ortak olarak sonuçlanan uygun olmayan bölgelerin haritası oluşturulmuştur (Şekil 3). İkinci adımda ise ilk aşamada klasik mantığa dayanan yöntem ve ikinci adımda bulanık mantığa dayanan yöntem ile GES için uygunluk haritaları oluşturulmuştur.

\subsection{Uygun Olmayan Bölgelerin Belirlenmesi}

Tablo 1'de belirlenen kriterler dikkate alınarak öncelikle her bir kriter için ayrı ayrı tampon bölge analizi gerçekleştirilmiştir. Böylece, uygun olmayan alanlar belirlenmiş ve ikinci adım ile bu alanlar birleştirilmiştir. Bu birleştirme işleminde; bir alanın herhangi bir kriter bakımından uygunsuz olması durumunda, diğer kriterlere bakılmaksızın uygunsuz olarak kabul edilmiştir. Şekil 3'te uygun olmayan bölgelerin sonuç haritası verilmiştir.

Elde edilen sonuçlar neticesinde çalışma alanının \%65.91'inin GES kurulumuna uygun olmadığı anlaşılmıştır. Uygun olmayan alanların yüz ölçümü $502.9 \mathrm{~km}^{2}$ iken, $260.1 \mathrm{~km}^{2}$ ise uygun alan olarak tespit edilmiştir. Daha sonraki adımda ise iki farklı yöntem ile uygun olarak sonuçlanan alanların uygunluk seviyelerinin belirlenmesi işlemine geçilmiştir.

\subsection{Klasik Mantığa Dayanan Yöntem}

Çalışmanın ilk aşamasında klasik mantığa dayanan yöntem kullanılarak Tablo 1'deki değerler dikkate alınarak her bir kriter bakımından ayrı ayrı uygunluk haritaları oluşturulmuştur. Bu haritalar ArcGIS 10.5 programı ile birçok mekânsal analiz; tampon bölge oluşturma, birleştirme, raster yapısına dönüşüm, değerlerin tersini alma, değerleri sıfırlama ve raster 
hesaplayıcı vb. kullanılarak oluşturulmuştur (Şekil 4).

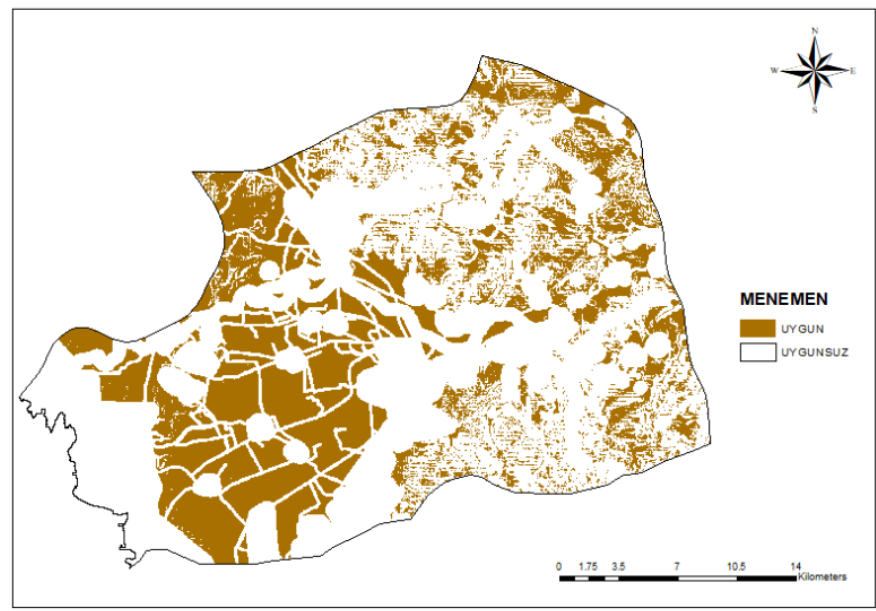

Şekil 3: Uygun olmayan alanların sonuç haritası

Her bir kriter bakımından ayrı ayrı uygunluk haritaları oluşturulmasından sonra kriterlerin AHS yöntemi kullanılarak ağırlıklandırılması işlemine geçilmiştir. Tablo 6'da ikili karşılaştırma matrisi ve yapılan matematiksel işlemler sonucu elde edilen ağırlıklar verilmiştir. Aynı zamanda ikili karşılaştırma matrisinin tutarlılığını belirten CR değeri, 0.073 hesaplanmış ve 0.10 değerinden küçük çıkması sonucu modelin tutarlı olduğu anlaşılmıştır.

Tablo 6: AHS ikili karşılaştırma matrisi ve elde edilen ağırlıklar

\begin{tabular}{|c|c|c|c|c|c|c|c|}
\hline & ENH & Eğim & Arazi Kullanımı & Yollar & Akarsular & Göller & Ağırlıklar (\%) \\
\hline $\mathrm{ENH}$ & 1 & 3 & 5 & 5 & 7 & 7 & 44.04 \\
\hline Eğim & $1 / 3$ & 1 & 3 & 3 & 5 & 5 & 22.84 \\
\hline Arazi Kullanımı & $1 / 5$ & $1 / 3$ & 1 & 3 & 3 & 5 & 14.44 \\
\hline Yollar & $1 / 5$ & $1 / 3$ & $1 / 3$ & 1 & 3 & 3 & 9.30 \\
\hline Akarsular & $1 / 7$ & $1 / 5$ & $1 / 3$ & $1 / 3$ & 1 & 3 & 5.78 \\
\hline Göller & $1 / 7$ & $1 / 5$ & $1 / 5$ & $1 / 3$ & $1 / 3$ & 1 & 3.60 \\
\hline
\end{tabular}

AHS ile yapılan ağırlıklandırma sonucunda \%44.04 ile en yüksek ağırlığa ENH'nin sahip olduğu daha sonra bunu sırasıyla eğim, arazi kullanımı, yollar, akarsular ve göllerin izlediği hesaplanmıştır. Kriterlerin AHS ile hesaplanan ağırlıkları göz önüne alınarak Şekil 4'te bulunan haritalar birleştirilip, uygunsuz alanlar bu haritadan çıkarılarak çalışma alanı için GES uygunluk haritası oluşturulmuştur (Şekil 5).

Klasik mantığa dayanan birinci yöntemin sonuçları neticesinde çalışma alanının \%65.91'inin GES kurulumuna uygunsuz, \%0.38'inin az, \%11.63'ünün orta, \%22.08'inin ise yüksek uygunlukta olduğu hesaplanmıştır.

\subsection{Bulanık Mantığa Dayanan Yöntem}

Öncelikle klasik mantığa dayanan yöntemde olduğu gibi her bir kriter bakımından ayrı ayrı uygunluk haritaları oluşturulmuştur. Bu aşamada klasik mantığa dayanan yöntemde kullanılan aynı mekânsal analizler kullanılmıştır. Fakat, bu uygunluk haritaları klasik mantıktakinden farklı olarak 0 ile 1 arasındaki sürekli değerlerden oluşmakla birlikte Bölüm 3.4 ile açıklanan eşitlikler kullanılarak elde edilmiştir (Şekil 6). 


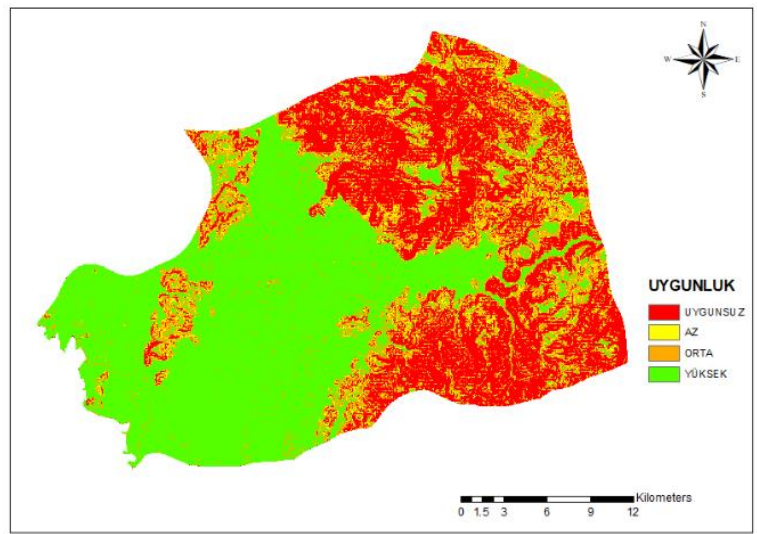

a) Eğim bakımından uygunluk haritası

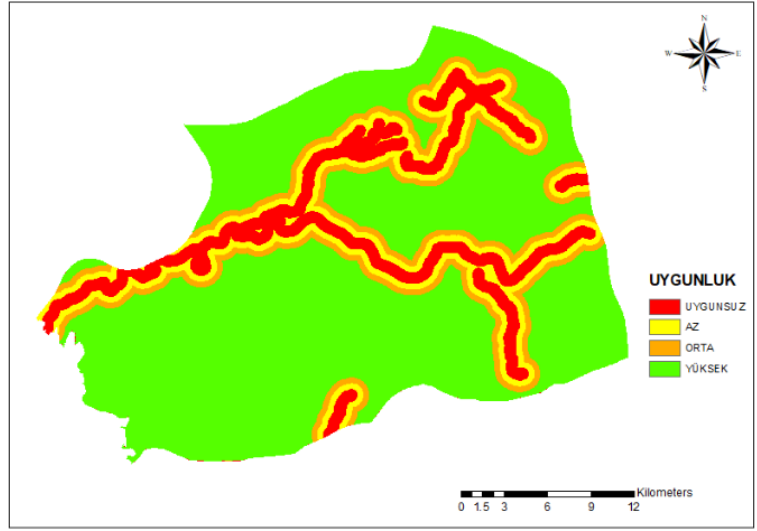

c) Akarsular bakımından uygunluk haritası

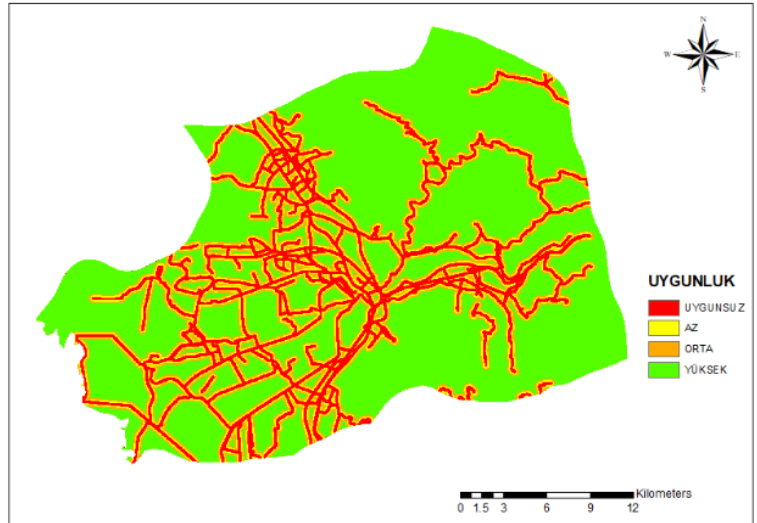

e) Yollar bakımından uygunluk haritası

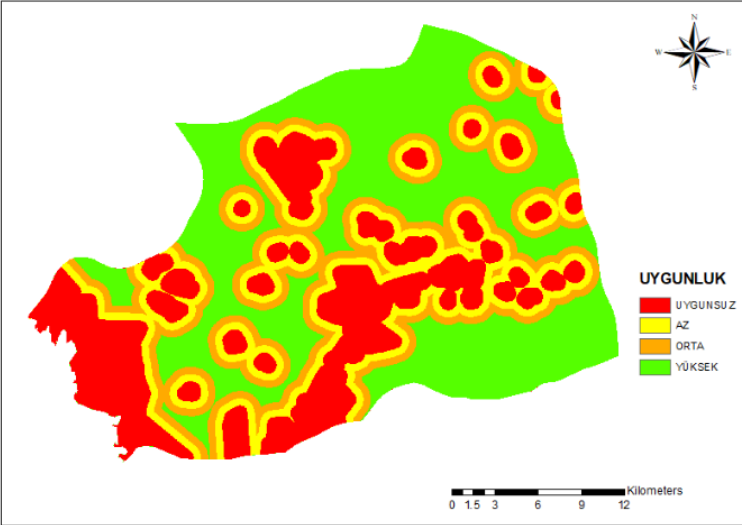

b) Arazi kullanımı bakımından uygunluk haritası

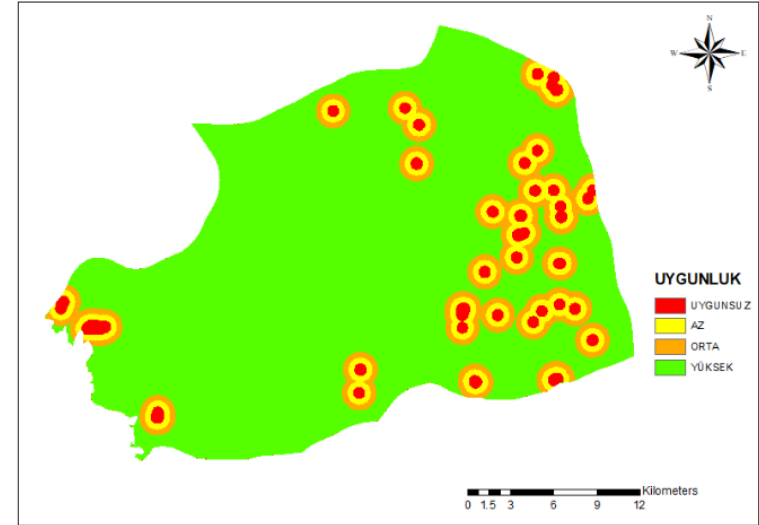

d) Göller bakımından uygunluk haritası

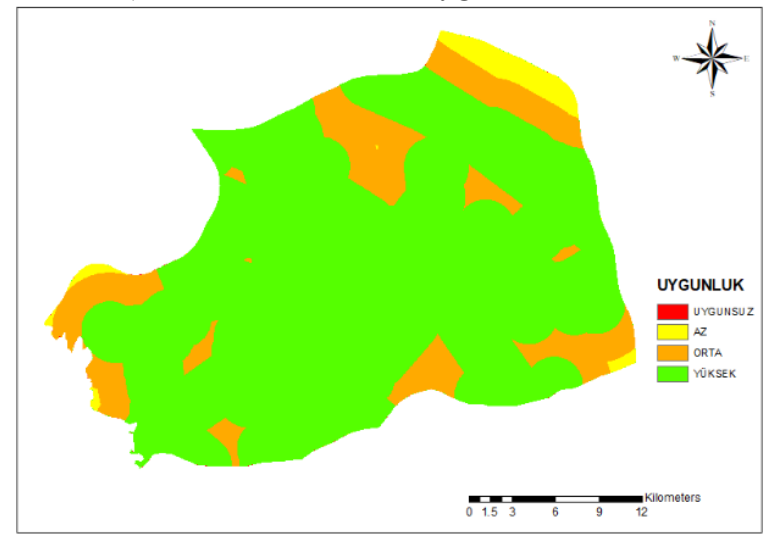

f) ENH bakımından uygunluk haritası

Şekil 4: Her bir kriter bakımından ayrı ayrı uygunluk haritaları

BAHS ile her bir kriter bakımından ayrı ayrı uygunluk haritaları oluşturulduktan sonra kriterlerin BAHS kullanılarak ağırlıklandırılmasına geçilmiştir. Tablo 7'de ikili karşılaştırma matrisi ve Tablo 8'de yapılan matematiksel işlemler sonucu elde edilen ağırlıklar verilmiştir.

Tablo 7: BAHS için ikili karşılaştırma matrisi

\begin{tabular}{|c|c|c|c|c|c|c|c|c|c|c|c|c|c|c|c|c|c|c|}
\hline Kriter & \multicolumn{3}{|c|}{ ENH } & \multicolumn{3}{|c|}{ Eğim } & \multicolumn{3}{|c|}{ Arazi Kullanımı } & \multicolumn{3}{|c|}{ Yollar } & \multicolumn{3}{|c|}{ Akarsular } & \multicolumn{3}{|c|}{ Göller } \\
\hline ENH & 1 & 1 & 1 & 1 & 3 & 5 & 3 & 5 & 7 & 3 & 5 & 7 & 5 & 7 & 9 & 5 & 7 & 9 \\
\hline Eğim & 1 & $1 / 3$ & $1 / 5$ & 1 & 1 & 1 & 1 & 3 & 5 & 1 & 3 & 5 & 3 & 5 & 7 & 3 & 5 & 7 \\
\hline Arazi Kullanımı & $1 / 3$ & $1 / 5$ & $1 / 7$ & 1 & $1 / 3$ & $1 / 5$ & 1 & 1 & 1 & 1 & 3 & 5 & 3 & 5 & 7 & 3 & 5 & 7 \\
\hline Yollar & $1 / 3$ & $1 / 5$ & $1 / 7$ & 1 & $1 / 3$ & $1 / 5$ & 1 & $1 / 3$ & $1 / 5$ & 1 & 1 & 1 & 1 & 3 & 5 & 1 & 3 & 5 \\
\hline Akarsular & $1 / 5$ & $1 / 7$ & $1 / 9$ & $1 / 3$ & $1 / 5$ & $1 / 7$ & $1 / 3$ & $1 / 5$ & $1 / 7$ & 1 & $1 / 3$ & $1 / 5$ & 1 & 1 & 1 & 1 & 3 & 5 \\
\hline Göller & $1 / 5$ & $1 / 7$ & $1 / 9$ & $1 / 3$ & $1 / 5$ & $1 / 7$ & $1 / 3$ & $1 / 5$ & $1 / 7$ & 1 & $1 / 3$ & $1 / 5$ & 1 & $1 / 3$ & $1 / 5$ & 1 & 1 & 1 \\
\hline
\end{tabular}




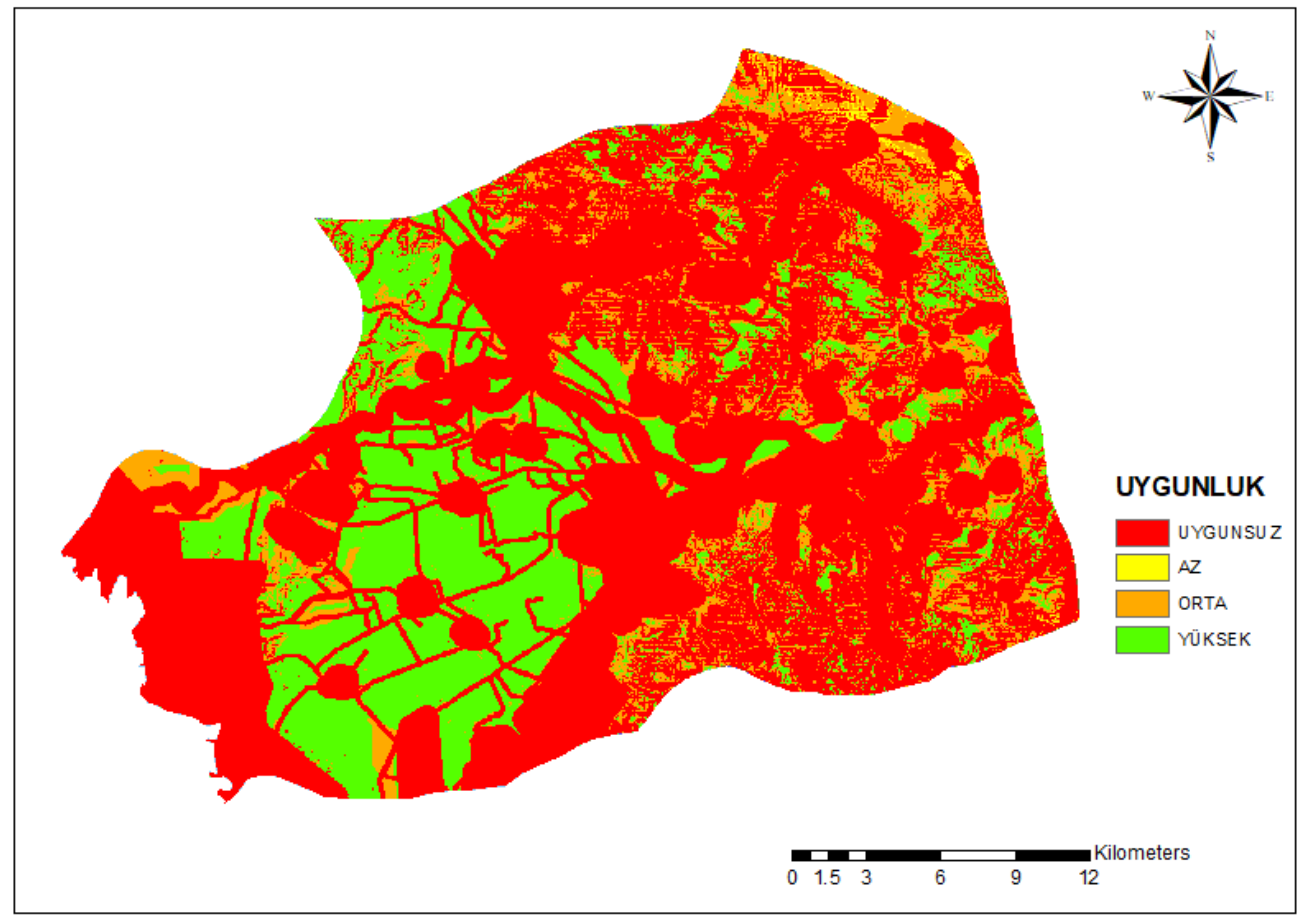

Şekil 5: Çalışma alanı için GES uygunluk haritası (1. yöntem)

Tablo 8: BAHS için kriterlerin ağırlıkları

\begin{tabular}{cc}
\hline Kriter & A ğırlık \\
\hline ENH & 45.24 \\
\hline Eğim & 23.13 \\
\hline Arazi Kullanımı & 14.64 \\
\hline Yollar & 8.57 \\
\hline Akarsular & 4.78 \\
\hline Göller & 3.63 \\
\hline
\end{tabular}

BAHS ile yapılan ağırlıklandırma sonucunda \%45.24 ile en yüksek ağırlığa ENH’nin sahip olduğu daha sonra bunu sırasıyla eğim, arazi kullanımı, yollar, akarsular ve göllerin izlediği hesaplanmıştır. Kriterlerin BAHS ile hesaplanan ağırlıkları göz önüne alınarak Şekil 6'da bulunan haritalar birleştirilip uygunsuz alanlar bu haritadan çıkarılarak çalışma alanı için GES uygunluk haritası oluşturulmuştur (Şekil 7).

Elde edilen bu sonuç haritası neticesinde çalışma alanında bulunan alanların uygunluğu 0 ile 0.86 arasındaki sürekli değerler ile ifade edilmiştir. Birinci yöntemde ise uygunluklar uygunsuz, az, orta ve yüksek olmak üzere dört kesik değer ile ifade edilmiştir. İki haritanın karşılaştırılması amacıyla Şekil 7'de bulunan 0 ile 0.86 arasındaki değerler dört kesik değere eşit aralıklarla bölünmüştür (Şekil 8).

Yapılan bu işlem sonucunda çalışma alanının \%65.91'i GES kurulumuna uygunsuz, \%4.91'i az, \%13.52'si orta, \%15.61'i ise yüksek uygunlukta olduğu hesaplanmıştır.

\subsection{Klasik ve Bulanık Mantığa Dayanan Yöntemlerin Analiz Sonuçları}

Menemen bölgesi için klasik ve bulanık mantığa dayanan yöntemlerin analiz sonuçları incelenmiştir. Elde edilen ağırlıklandırma sonuçlarında ise çok büyük bir fark ortaya çıkmamıştır. Tablo 9' da verilen ağırlıklar incelendiğinde farkların 0.03 ila 1.20 arasında değiştiği tespit edilmiştir. Fakat BAHS' de yüksek önem derecesine sahip kriter ağırlığı artarken, diğer kriterlere ait ağırlıkların ise azaldığı tespit edilmiştir. Buradan BAHS’nin iyi olanı daha yukarı çekerken, kötü olanı da daha 
aşağı iterek sonucu belirginleştirdiği ortaya çıkarılabilir. Bu sonuç AHS ve BAHS karşılaştırması bakımından, Denizhan vd. (2017) tarafından, AHS ve BAHS kullanılarak yeşil tedarikçi seçimi için yapılan çalışmanın sonucunda da elde edilen çalışma sonucu ile aynı bulguların tespit edildiğini göstermektedir.

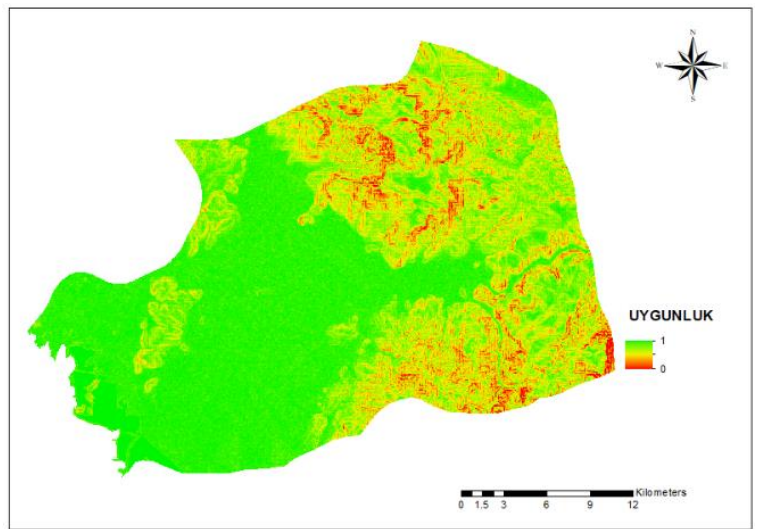

a) Eğim bakımından uygunluk haritası

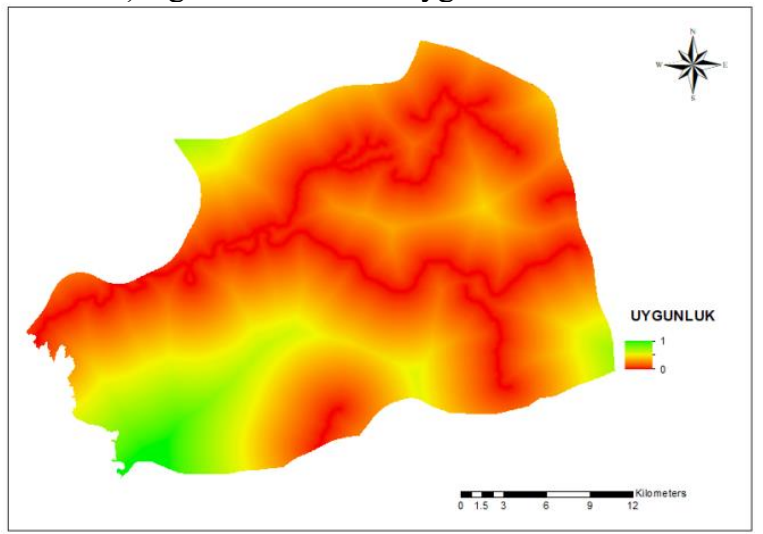

c) Akarsular bakımından uygunluk haritası

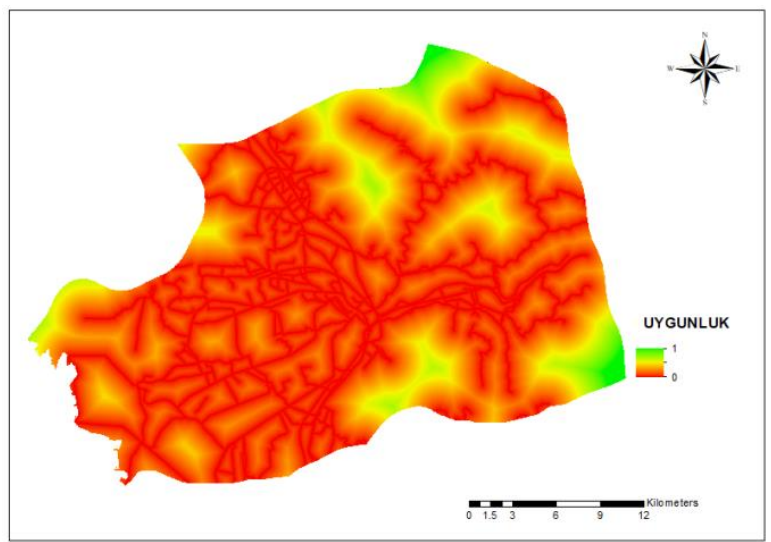

e) Yollar bakımından uygunluk haritas1

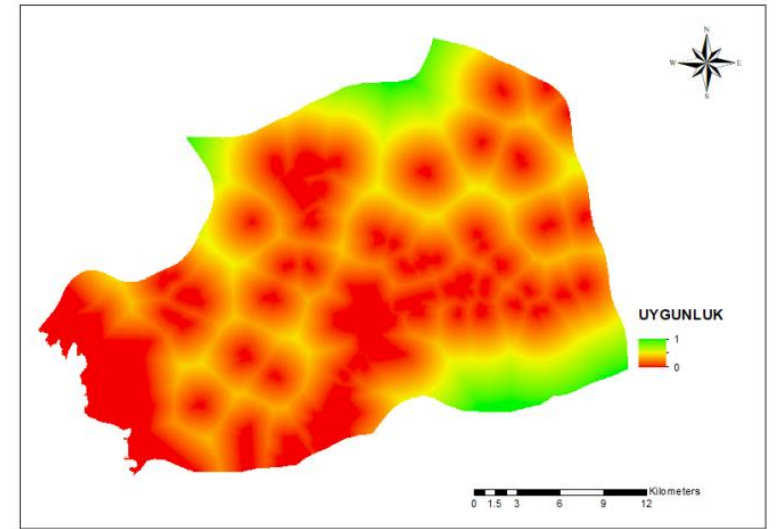

b) Arazi kullanımı bakımından uygunluk haritası

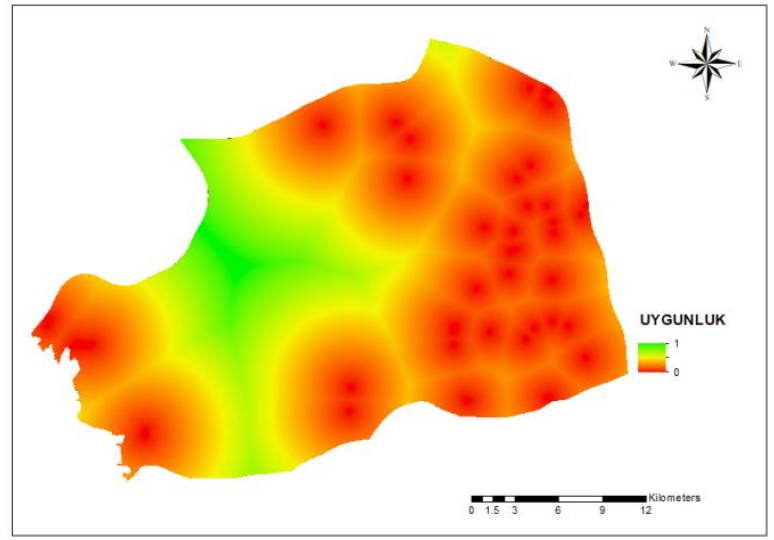

d) Göller bakımından uygunluk haritası

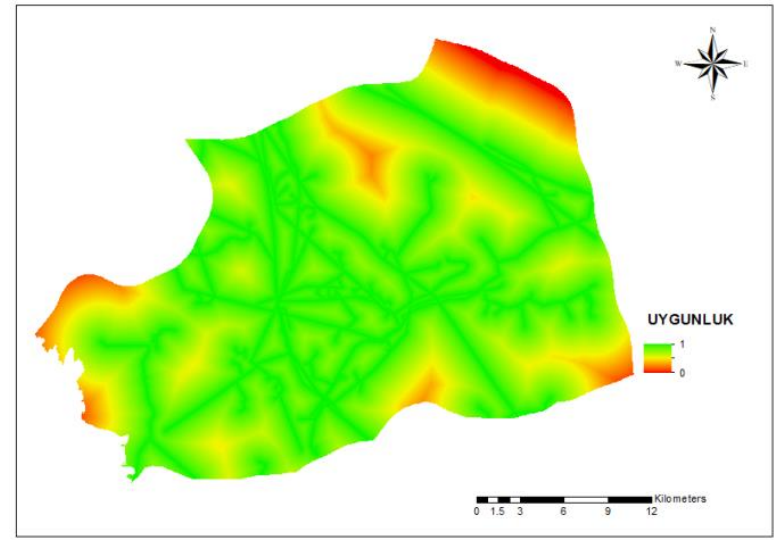

f) ENH bakımından uygunluk haritası

Şekil 6: BAHS ile elde edilen her bir kriter bakımından ayrı ayrı uygunluk haritaları

Ağırlıklandırmada iki yöntem arasındaki farkın az çıkmasının sebebi ise, AHS ile BAHS yöntemleri kullanılarak kriterlerin birbirlerine göre üstünlüklerini ifade ederken her iki yöntemde de aynı sözel ifadelerin kullanılmasıdır. Başka bir ifade ile ENH ile eğim karşılaştırılırken her iki yöntemde de “ENH'nin, eğime göre biraz daha fazla önemli” olduğu kabul edilmiş ve AHS'de 3 değeri kullanılırken BAHS'de 1-3-5 değeri kullanılmıştır. Bunun yanında kriter sayısının az olması ve alt kriterlerin bulunmaması da bir başka etken olarak karşımıza çıkmaktadır. 


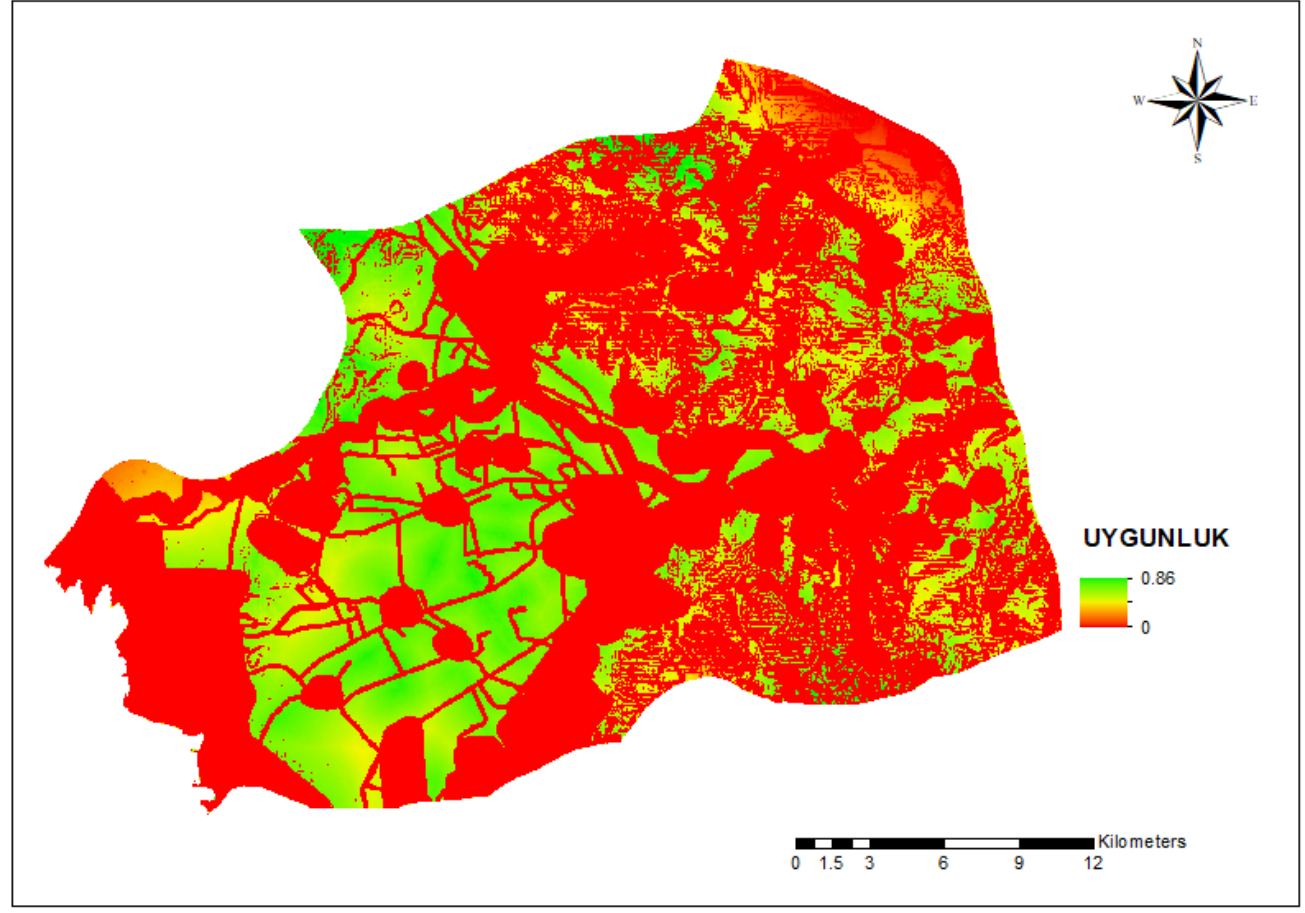

Şekil 7: Çalışma alanı için GES uygunluk haritası (2. yöntem)

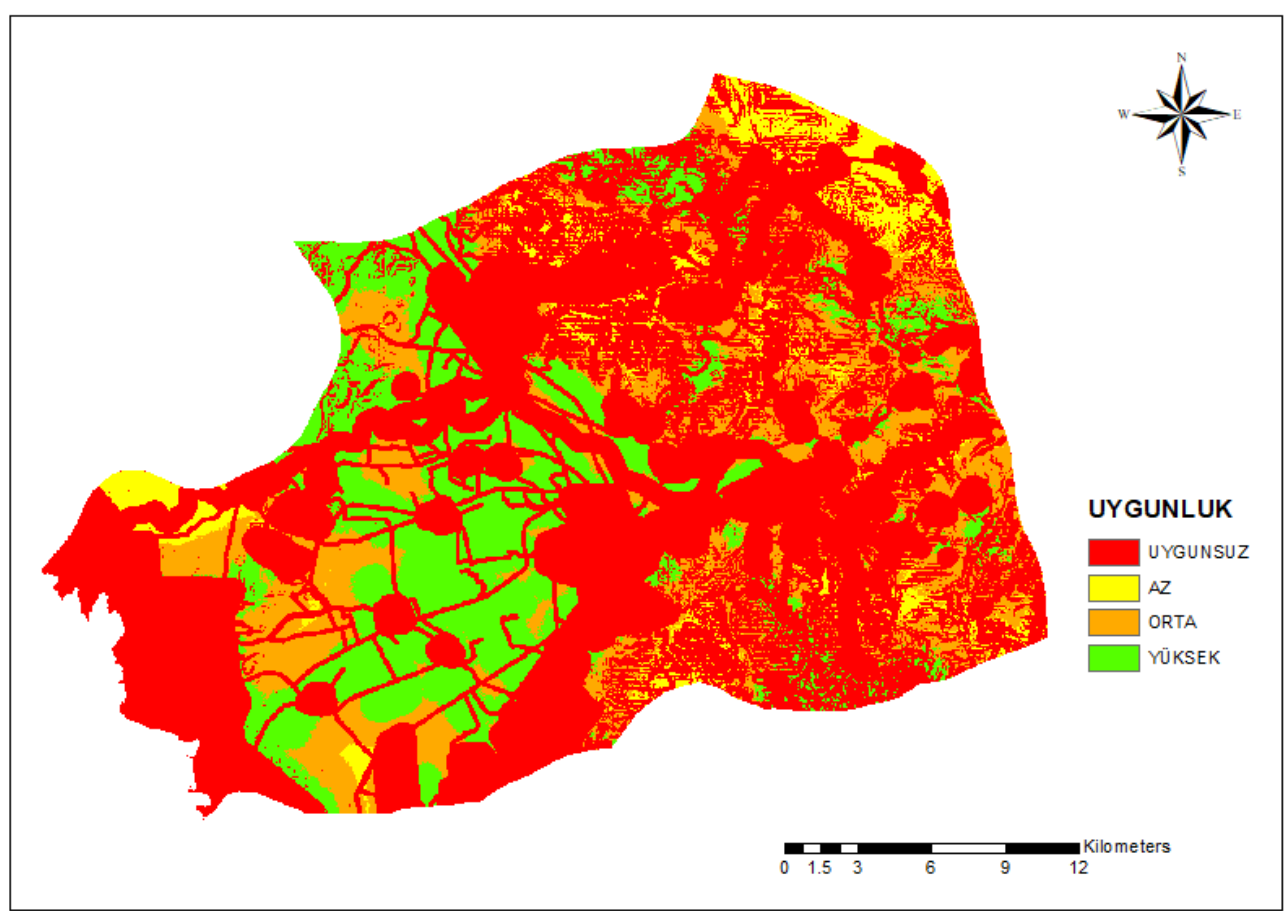

Şekil 8: Çalışma alanı için 4 değer ile GES uygunluk haritası

Tablo 9: AHS ve BAHS için elde edilen ağırlıklar

\begin{tabular}{ccc}
\hline Kriter & AHS Ă̆ırlıklar (\%) & BAHS A ̈̆ırlıklar (\%) \\
\hline ENH & 44.04 & 45.24 \\
\hline Eğim & 22.84 & 23.13 \\
\hline Arazi Kullanımı & 14.44 & 14.64 \\
\hline Yollar & 9.30 & 8.57 \\
\hline Akarsular & 5.78 & 4.78 \\
\hline Göller & 3.60 & 3.63 \\
\hline
\end{tabular}


Yapılan analizler sonucunda bulanık mantık yönteminin uygulanmasında sadece ağırlıklandırma aşamasında bulanık mantığın kullanılmasının yeterli olmadığı görülmüştür. Bu kapsamda, alternatiflerin de bulanıklaştırılması gerektiği tespit edilmiştir. Her iki yöntemin de ikinci adımı olan uygunluk haritalarının oluşturulmasında, klasik mantığa dayanan ilk yöntemde, uygunlukların ifadesinde dört kesik değer kullanılırken; bulanık mantığa dayanan ikinci yöntemde, 0 ile 1 arasındaki sürekli değerler kullanılarak alternatifler de ağırlıklandırılmıştır. Bunun sonucunda Tablo 10'da yöntemler ve uygunluk değerleri elde edilmiştir. Kullanılan bu iki yöntemin uygunluk analiz sonuçlarında az, orta ve yüksek uygunluk için sırasıyla 4.58, 1.89 ve 6.47 farklılık değerleri ortaya çıkmıştır.

Tablo 10: Uygunluklar

\begin{tabular}{ccc}
\hline Seviye / Yöntem & Klasik Yöntem & Bulanık Yöntem \\
\hline Uygun Olmayan & 65.91 & 65.91 \\
\hline Az Uygun & 0.38 & 4.96 \\
\hline Orta Uygun & 11.63 & 13.52 \\
\hline Yüksek Uygun & 22.08 & 15.61 \\
\hline
\end{tabular}

GES'lerin yer seçimi için uygunluk haritasının oluşturulması mekânsal karar problemi olarak ele alınmıştır. Bu sebep ile çok sayıda alternatif olması, bazı ölçütlerin kalitatif bazılarının ise kantitatif olması ve birden fazla sayıda karar vericinin bu işleme dahil olması sonuçları etkilemektedir. Bu aşamada CBS’nin rolü ise verilerin anlaşılabilir bir formda entegrasyonunu ve görselleştirilmesini sağlayarak karar verme sürecinde yardımcı olmasıdır. Bu çalışmada GES yer seçimi için CBS tabanlı mekânsal karar destek sisteminde sorgulama, tampon analizi, çakıştırma analizi ve komşuluk analizi gibi temel analitik fonksiyonlar kullanılmıştır. Literatürde yaygın kullanılan AHS ve BAHS yöntemlerinin bu uygulamadaki sonuçları analiz edildiğinde; ikili karşılaştırma aşamasında birbirlerine göre üstünlüklerini ifade ederken her iki yöntemde de aynı sözel ifadelerin kullanılmasında ağırlıkların birbirine çok yakın değerler aldığı ve sıralamaların değişmediği tespit edilmiştir. Fakat, alternatiflerinde bulanıklaştırılmasında kesik değerler yerine sürekli değerler kullanılması ile iki yöntem arasında fark ortaya çıkmış ve en uygun değer daha iyi bir şekilde ifade edilmiştir. Yapılan çalışma ile Özyılmaz Küçükyağc1 ve Ocakçı (2019) tarafından yapılan çalışma karşılaştırıldığında, bulanık mantık yönteminin kullanıldığı kentsel alanlara ilişkin 11 makalenin incelendiği çalışmada da bulanık mantığın kullanılması ile daha hassas, doğru ve somut sonuçlar elde edilmesi ile aynı bulguların elde edildiği gözlemlenmiştir.

\section{Sonuçlar}

GES için uygunluk haritasını belirlenmesine yönelik yapılan bu çalışmada kullanılan her iki yöntemde de çalışma alanı olan Menemen bölgesinin büyük bir potansiyel taşıdığı görülmüştür. Her iki yöntem de iki ana adımdan oluşmaktadır. İlk adım kriterleri ağırlıklandırmak ve ikinci adım ise uygunluk haritalarını oluşturmaktır. Kriterleri ağırlıklandırma aşamasında her iki yöntemde de ikili karşılaştırmalar yapmak karar vericiye oldukça kolaylık sağlamıştır. Uygunluk haritalarını oluşturma aşamasında ilk olarak her iki yöntemde de ortak olarak sonuçlanan uygun olmayan bölgelerin haritası oluşturulmuştur. İkinci adımda ise ilk aşamada klasik mantığa dayanan yöntem ve ikinci adımda bulanık mantığa dayanan yöntem ile GES için uygunluk haritaları oluşturulmuştur. Elde edilen analiz sonuçları neticesinde Menemen bölgesine ait GES'lerin kurulumu için, klasik mantığa dayanan birinci durumda \%65.91'inin uygunsuz, \%0.38'inin az, \%11.63'ünün orta, \%22.08'inin ise yüksek uygunlukta olduğu tespit edilmiştir. Bulanık mantığa dayanan ikinci durumda ise \%65.91'inin uygunsuz, \%4.96'sının az, \%13.52'sinin orta, \%15.61'inin ise yüksek uygunlukta olduğu tespit edilmiştir.

Uygun olmayan alanların belirlenmesinde aynı kriterler ve yöntem kullanıldı̆̆ı için her iki yöntemde yüzdeler aynıdır. Diğer uygunluk seviyelerinde ise bulanık mantıkta daha homojen ve gerçeğe yakın sonuçlar elde edildiği görülmektedir. Bunu bir alan ile örneklendirmek gerekirse: akarsular bakımından uygunluk haritası oluşturulurken akarsuya uzaklığı biri 799 m diğeri 
800 m olan iki alanı ele alalım. Klasik mantıkta 799 m’de bulunan alan 1 değeri alırken; 800 m'deki alan 2 değeri alacaktır. Fakat bulanık mantıkta 799 m'deki alan 0.06950 değeri alırken; 800 m'deki alan 0.06959 değeri alacaktır. Bu değerlerden anlaşılacağı üzere klasik mantığa dayanan ilk yöntemdeki kesik değerler yerine bulanık mantığa dayanan ikinci yöntemdeki sürekli değerler çalışmanın tutarlılığını arttıracak ve gerçeği daha iyi şekilde yansıtmasını sağlayacaktır. Özellikle GES'ler için uygunluk haritalarının oluşturulmasında etkili olan sosyal, ekonomik ve çevresel faktörlerin dikkate alınmasında ortaya çıkan minimum ve maksimum farkların oldukça önemli olduğu gözlemlenmiştir.

AHS yönteminde karar verici tarafından bir ölçütün bir diğer ölçüte göre ne kadar önemli olduğuna ikili karşılaştırma ile karar verilmesi sürecinde, sözel belirsizliği daha iyi ifade etmek için BAHS tercih edilmelidir. Özellikle ikili karşılaştırmaların fazla olması, karar vericide bulanıklık oluşması ve işlemlerin çok uzun zaman alması gibi durumlarda BAHS yönteminin tercih edilmesi önerilmektedir. Çevresel, sosyal ve ekonomik kriter ve alt kriterlerdeki sözel ifadelerin matematiksel ifadesi için bulanık ilişki ile entegre edilmesi daha doğru sonuçların elde edilmesinde önemlidir. Buna karşın, AHS yöntemi, iyi tanımlanmış ve tahlil edilmiş kesin ifadelerin olduğu, kriterler ve alternatiflerin fazla olmadığı durumlarda mekânsal karar verme problemlerinde kullanılarak doğru sonuçlar elde edilecektir. AHS yönteminin yeterli olacağı durumlarda, BAHS yönteminin kullanılması ile zaman sürecinin fazla olacağı, matematiksel ifadelerin fazlalığ ile bulanık değerlerin sınırlarının doğru tespit edilememesi gibi önemli adımların, sonuçları olumsuz etkileyeceği de göz önünde bulundurulmalıdır. Aksi halde, BAHS yöntemi doğru sonuç vermeyecektir. Sonuçta, mekânsal karar verme problemlerinde öncelikle amaç, kriterler ve alternatif alt kriterlerin sayısı, sözel verilerin bulanık matematiksel ifadeler ile temsilinin gerekliliği gibi önemli adımlar belirginleştirilerek AHS ve BAHS yöntemlerinin kullanımı tercih edilmelidir.

\section{Teşekkür}

Harita Genel Müdürlüğüne, sağlamış olduğu 1/50 000 ölçekli URLA K-17-c ve İZMIR K-18-d topoğrafik haritalar için teşekkür ederiz.

\section{Kaynaklar}

Al Garni, H. Z., \& Awasthi, A. (2017). Solar PV power plant site selection using a GIS-AHP based approach with application in Saudi Arabia. Applied energy, 206, 1225-1240.

Ayhan, M. B. (2013). A fuzzy AHP approach for supplier selection problem: A case study in a Gear motor company. International Journal of Managing Value and Supply Chains, 4(3), 11-23.

Asakereh, A., Soleymani, M., \& Sheikhdavoodi, M. J. (2017). A GIS-based Fuzzy-AHP method for the evaluation of solar farms locations: Case study in Khuzestan province, Iran. Solar Energy, 155, 342-353.

Buckley, J. J. (1985). Fuzzy hierarchical analysis. Fuzzy sets and systems, 17(3), 233-247.

Chou, S. W., \& Chang, Y. C. (2008). The implementation factors that influence the ERP (enterprise resource planning) benefits. Decision support systems, 46(1), 149-157.

Denizhan, B., Yalçıner, A. Y., \& Berber, Ş. (2017). Analitik hiyerarşi proses ve bulanık analitik hiyerarşi proses yöntemleri kullanılarak yeşil tedarikçi seçimi uygulaması. Nevşehir Bilim ve Teknoloji Dergisi, 6(1), 63-78.

Eroğlu, H. (2018). Güneş Enerji Santralleri İçin Uygunluk Haritasının Elde Edilmesi: Bir Uygulama. Iğdır Üniversitesi Fen Bilimleri Enstitüsü Dergisi, 8(4), 97-106.

Gül, A., Karakoç, A., \& Rehimbeyli, S. (2017). Mekansal Planlama Alan Kullanım Kararlarında Güneş Enerji Santrallerinin Yer Seçimi Kriterleri. 5th International Symposium on Innovative Technologies in Engineering and Science 29-30 September 2017 (ISITES2017 Baku-Azerbaijan).

Merrouni, A. A., Elalaoui, F. E., Mezrhab, A., Mezrhab, A., \& Ghennioui, A. (2018). Large scale PV sites selection by combining GIS and Jeo. Jeolnf. Derg., 2020, 7(1):11-28 
Analytical Hierarchy Process. Case study: Eastern Morocco. Renewable energy, 119, 863-873.

Noorollahi, E., Fadai, D., Akbarpour Shirazi, M., \& Ghodsipour, S. (2016). Land suitability analysis for solar farms exploitation using GIS and fuzzy analytic hierarchy process (FAHP)—a case study of Iran. Energies, 9(8), 643.

Özyılmaz Küçükyağcı, P., \& Ocakçı, M. (2019). Bulanık Mantık Yönteminin Kentsel Alan Çalışmalarında Kullanımı. Kent Akademisi, 12(2), 299-308.

Potić, I., Golić, R., \& Joksimović, T. (2016). Analysis of insolation potential of Knjaževac Municipality (Serbia) using multi-criteria approach. Renewable and Sustainable Energy Reviews, 56, 235-245.

Saaty, T. L., \& Vargas, L. G. (2012). Models, methods, concepts \& applications of the analytic hierarchy process (Vol. 175). Springer Science \& Business Media.

Supçiller, A., \& Çapraz, O. (2011). Ahp-topsis yöntemine dayali tedarikçi seçimi uygulamasi. Ekonometri ve İstatistik e-Dergisi, (13), 122.

Şenlik, İ. (2017). Güneş Enerjisi Santrallarının Yer Seçimi, Elektrik Mühendisliği Dergisi, 462, 94- 98.

Uyan, M. (2013). GIS-based solar farms site selection using analytic hierarchy process (AHP) in Karapinar region, Konya/Turkey. Renewable and Sustainable Energy Reviews, 28, 11-17.

Uzar, M., \& Şener, Z. (2019). Suitable map analysis for wind energy projects using remote sensing and GIS: a case study in Turkey. Environmental Monitoring and Assessment, 191(7), 459.

Uzar, M., \& Asılhan, E. F. (2019) İnternet tabanlı harita üretiminde karar destek sistemleri ve coğrafi bilgi sistemi destekli alternatif yaklaşım: müsabaka yöntemi. Jeodezi ve Jeoinformasyon Dergisi, 6(1), 47-60.

URL-1: Yenilenebilir Enerji Genel Müdürlüğü, Güneş Enerji Potansiyel Atlas1, http://www.yegm.gov.tr/MyCalculator/pages/35.aspx, (Erişim Tarihi: 5 Ağustos 2019).

URL-2: Enerji Atlası, İzmir Güneş Enerjisi Potansiyeli Haritası, http://www.enerjiatlasi.com/gunes-enerjisi-haritasi/izmir, (Erişim Tarihi: 5 Ağustos 2019). 